\title{
М. М. Костенко
}

\section{ТЕКТОНІЧНА БУДОВА ФУНДАМЕНТУ БУЗЬКО-РОСИНСЬКОГО МЕГАБЛОКА УКРАÏНСЬКОГО ЩИТА}

\author{
(Рекомендовано канд. геол.-мінерал. наук В. Я. Велікановим)
}

Рассмотрено тектоническое строение Бугско-Росинского мегаблока, который предлагается выделить в качестве самостоятельного геоструктурного элемента Украинского щита, с позиций разломно-блоковой тектоники. В его пределах выделены блоки разных рангов, которые характеризуються различным уровнем эрозионного среза и отличаются между собой особенностями геофизических полей, составом стратифицированных и нестратифицированных образований и, соответственно, разной степенью метаморфизма (от гранулитовой к амфиболитовой фации) и гранитизации.

The tectonic structure of the Bug-Ross megablock is examined. This megablock is proposed to distinguish as a separate structural unit of the Ukrainian Shield on the theory of fault-block tectonics. It is subdivided into blocks of lower ranks which are differed in levels of erosion profile, characteristics of geophysical fields, the composition of the stratified and unstratified rock complexes and, respectively, in their degree of metamorphism (from granulite to amphibolite facies) and granitization.

\section{Вступ}

Бузько-Росинський мегаблок є великим сегментом Українського щита (УЩ), який охоплює значну частину БілоцерківськоОдеської (Брусилівсько-Одеської) структурно-формаційної зони. Ця зона чітко простежується в фізичних полях і перетинає поперек майже в субмередіональному напрямку західну частину щита (ближче до його центра) і далі простежується на його схилах: на північному зануренні в фундаменті Дніпровсько-Донецької западини, а на південному - Молдавської плити. Вперше як Брусилівсько-Одеська зона виділена Я. М. Бєлєвцевим і А. К. Прусом [3] у зв'язку з відкриттям в її межах родовищ залізистих кварцитів. У подальшому уявлення про цю зону як самостійний структурний елемент УЩ (Білоцерківсько-Одеська зона) розвивалось у роботах Г. І. Каляєва, А. К. Пруса, М. О. Ярощук, М. М. Доброхотова та інших дослідників.

Слід зазначити, що в процесі довготривалого вивчення Білоцерківсько-Одеської зони погляди авторів на її тектонічну будову з роками змінювались. Спочатку вона розглядалась як складний синклінорій; при цьому породи східного і західного обрамлення структури вважались більш давніми (тобто вони складали давню протоплатформу). На

() М. М. Костенко, 2010 думку Г. І. Каляєва $[13,14]$, ця зона є однією з гілок Криворізької геосинкліналі. Як протерозойську геосинклінальну гілку чи систему (Ядловсько-Одеську), що розділяе Кіровоградський і Подільський протоплатформені блоки, її виокремлював також В. Б. Соллогуб із співавторами [20]. М. М. Доброхотов [9] розглядав Білоцерківсько-Одеську зону як західне крило Інгуло-Інгулецького синклінорія. При цьому поширене тоді уявлення про належність залізистих кварцитів до криворізької серії М. М. Доброхотов вважав недостатньо аргументованими на тій підставі, що криворізькі розрізи значно відрізняються від таких зазначеної зони, а саме: вмісними породами для залізистих кварцитів Криворіжжя слугують метаморфізовані теригенні породи, а не основні ефузиви, а також відсутністю карбонатних утворень. Складові ж зони нижнього ярусу він зіставляв 3 конксько-верхівцівською серією Середнього Придніпров'я.

Згідно з сучасними уявленнями, Білоцерківсько-Одеська структурно-формаційна зона являє собою неоархейську проторифтогенну систему, в якій розвинені метаморфічні й ультраметаморфічні утворення двох структурних ярусів: нижнього, складеного палеоархейськими структурно-формаційними комплексами, і верхнього, представленого неоархейськими комплексами [6-8, 13, 24, 25 та ін.]. На думку В. П. Безвинного [1, 2], в північній частині зони, в ме- 
жах Росинсько-Тікицького блока відбулось розширення проторифту, і він еволюціонував в океанічний басейн. Цей автор вважає, що протоконтинентальна кора в межах цього блока не утворювалась взагалі або внаслідок спредингу була трансформована в зону субдукції, у зв'язку з чим будова зазначеної геоструктури зараз є одноярусною.

\section{Постановка проблеми}

Відповідно до існуючого районування УЩ, у західній його частині традиційно виокремлюються Росинсько-Тікицький, Дністровсько-Бузький і Волинський мегаблоки та Голованівська шовна зона [16]. Причому південно-східним відгалуженням Дністровсько-Бузького мегаблока вважається і район Середнього Побужжя, через що конфігурація його границь зараз має складну форму. Під час вдосконалення нині діючого варіанта хроностратиграфічної схеми раннього докембрію нами було запропоновано дещо змінити районування УЩ [11]. Так, поряд з міжмегаблоковими шовними зонами пропонувалось виокремити в якості самостійного геоструктурного елемента щита Бузько-Росинський мегаблок. Ще раніше під такою назвою він фігурував у працях І. Б. Щербакова $[21,22]$ та В. П. Кирилюка і А. Г. Смоголюк [15].

Підставою для виокремлення зазначеного мегаблока слугували його структурна єдність, яка добре проявляється на картах гравітаційного і магнітного полів України, та уявлення про його двоярусну будову (на відміну від одноярусного Подільського). Нижній ярус цієї структури представлений гранулітовим, а верхній - амфіболіт-гранулітовим і амфіболітовим стратигенними структурно-речовинними комплексами. Останній був сформований в неоархейський час на палеоархейському деструктурованому фундаменті.

Проте на засіданні ранньодокембрійської секції НСК ця пропозиція не знайшла підтримки і була відхилена, оскільки вважалось, що Середньобузький район (блок) повністю складений лише палеоархейським ендербіт-гранулітовим структурно-речовинним комплексом [16]. Таке уявлення було зумовлене, з одного боку, недостатньою вивченістю південної частини мегаблока, а 3 іншого - не враховувався (чи ігнорувався) той факт, що на продовженні південного флангу Білоцерківсько-Одеської зони (на південному схилі щита - в межах Молдавської плити і в районі фрунзівських і ананьївських магнітних аномалій) вже на той час давно були відомі неоархейські утворення бузької серії, що свідчить про єдність геологічних подій, які відбувались в неоархеї на всій її території.

Варто відмітити, що за результатами новітніх геологічних досліджень, які вже виконані чи ще нині здійснюються з метою геологічного довивчення басейнів річок Рось, Гнилий Тікич, Південний Буг і Дністер, встановлені нові ділянки розвитку не тільки бузької, а й росинсько-тікицької серій, що, загалом, ставить питання про необхідність повернення до зазначеної вище пропозиції щодо виокремлення в якості самостійного геоструктурного елемента Ущ Бузько-Росинського мегаблока, який відповідно включав би блоки I і більш високого порядків [11].

\section{Мета досліджень та матеріали}

Мета цієї роботи - структурно-тектонічний аналіз території зазначеного мегаблока, побудова тектонічної схеми та надання характеристики його головних структурних елементів. В основу публікації покладено результати узагальнення і переосмислення матеріалів новітніх геологічних і геофізичних досліджень, проведених в регіоні 3 метою складання Держгеолкарти-200.

\section{Основні результати та їх обговорення}

Бузько-Росинський мегаблок відокремлюється на заході від Волинського і Подільського відповідно Чорнобильською, Брусилівською і Немирівською тектонічними зонами, а на сході від Інгульського - Ядлово-Трахтемирівською зоною розломів і Голованівською шовною зоною, з якою безпосередньо межує по Тальнівсько-Гвоздавському розлому (див. рисунок). Південним і північним його обмеженнями є границі щита.

Необхідно зауважити, що внаслідок широко проявлених у межах Бузько-Росинського мегаблока процесів гранітизації і через 


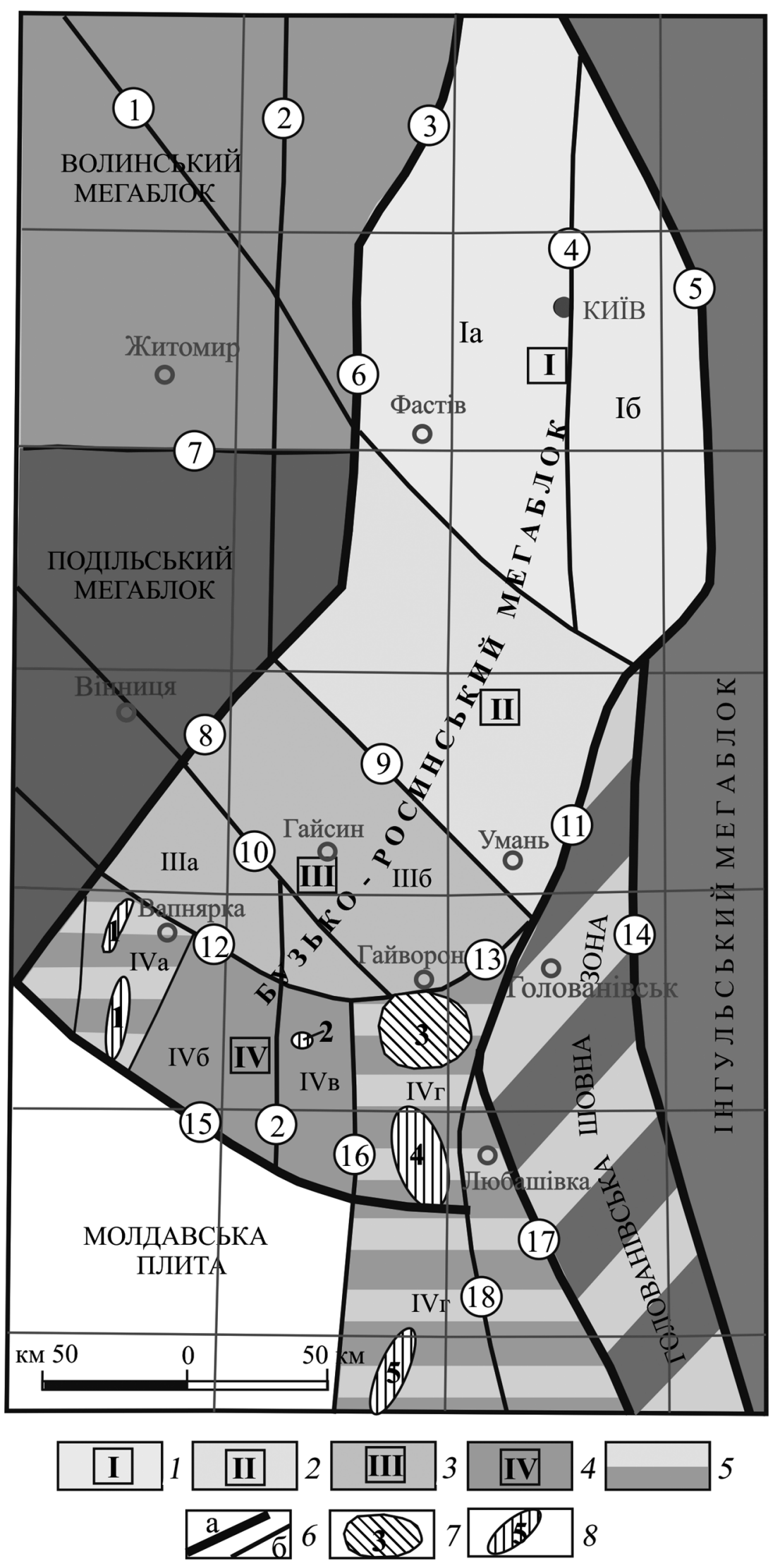




\section{Тектонічна схема фундаменту Бузько-Росинського мегаблока}

Росинсько-Тікицький блок I порядку: 1 - Білоцерківський блок II порядку (Іа - Фастівський та Іб - Бориспільський блоки III порядку); 2 - Уманський блок II порядку. Середньобузький блок I порядку: 3 - Гайсинський блок II порядку (IIIa - Тульчинський та IIIб - Теплицький блок III порядку); 4 - Кодимсько-Тилігульський блок II порядку $(I V a-$ Вапнярський, IVб - Павловський, IVB - Ольгопільський та $I V r$ - Завалівсько-Ананьївський блоки III порядку); 5 - блоки (структурно-формаційні підзони), в яких поряд з утвореннями нижньопротерозойського ендербіт-гранулітового структурно-формаційного комплексу поширені породи бузької і росинсько-тікицької серій неоархею; 6 - зони глибинних розломів ( $а$ - І рангу, б - II рангу); 7 - Бандурівський гравітаційний максимум; 8 синформні структури, складені породами карбонат-метабазит-залізисто-кременистої формації (1 - ВоронковоКосницька (Немирів-Воронково-Страшівська зона), 2 - Білокам'янська, 4 - Ананьївська, 5 - Фрунзівська). Зони розломів (цифри в кружках): 1 - Центрально-Коростенська, 2 - Звіздаль-Заліська, 3 - Чорнобильська, 4 Дарницька, 5 - Ядлово-Трахтемирівська, 6 - Брусилівська, 7 - Андрушівська, 8 - Немирівська, 9 - Дашівська, 10 - Хмільницька, 11 - Тальнівська, 12 - Ободівська, 13 - Гайворонська, 14 - Первомайська, 15 - Подільська, 16 - Котовська, 17 - Гвоздавська, 18 - Одеська

реліктову форму знаходження суперкрустальних утворень серед суцільного поля розвитку гранітоїдів плікативна тектоніка в цьому регіоні виражена дуже слабо. А тому виокремити в його межах великі плікативні структурні елементи, подібно до тих, що вирізняв раніше у своїй праці (переважно на підставі геофізичних даних) Г. І. Каляєв із співавторами [14] - Білоцерківську, Гайсинську і Бузько-Дністровську синклінорні та Ржищів-Бориспільську й УманськоТетіївську антиклінорні зони - практично неможливо. Як правило, однозначно серед гранітоїдів встановлюються лише невеликі лінзоподібні синформи.

Разом з тим внутрішня структура Бузько-Росинського мегаблока $є$ неоднорідною по латералі. По-перше, по простяганню він розбитий серією розломних зон глибинного закладення північно-західного напрямку (з півдня на північ): Подільською, Ободівською, Хмільницькою, Дашівською і Центральною [12]. По-друге, в межах мегаблока виокремлюються ділянки 3 різним рівнем ерозійного зрізу, які відповідно відрізняються між собою і різним ступенем метаморфізму (від гранулітової до амфіболітової фації) та гранітизації стратифікованих утворень. При цьому занурення архейської грануліт-ендербітової основи, а отже, і зменшення інтенсивності метаморфізму порід на сучасному ерозійному зрізі відбувається в північному напрямку. А все це свідчить про те, що визначальну роль у будові мегаблока відіграють різнорангові блокові структурні елементи, на що вже раніше звертала увагу М. А. Ярощук [24].

Так, за геологічною будовою поверхні сучасного ерозійного зрізу кристалічного фундаменту та глибинною будовою земної кори, а також за неоднорідностями прояву в геофізичних полях, зазначений мегаблок поділяється на два геологічних райони, яким надано статус блоків I порядку: РосинськоТікицький (північний) і Середньобузький (південний) [11]. В іншій праці вони фігурують як самостійні Росинський і Бузький мегаблоки [12]. Середньобузький мегаблок відрізняється від Росинсько-Тікицького широким розвитком в його межах утворень палеоархейського ярусу, підвищеним рівнем напруженості магнітного і гравітаційного полів, мозаїчним характером магнітного поля з поширеними аномаліями ізометричної й еліпсоподібної форми, підвищеною потужністю земної кори (50-65 км проти 4045 км). У кожному з виокремлених блоків за геологічною будовою і геофізичними полями вирізняються по два блоки II порядку: в Середньобузькому блоці - це КодимськоТилігульський і Гайсинський, а в РосинськоТікицькому - Уманський і Білоцерківський (див. рисунок).

Кодимсько-Тилігульський блок II порядку, складної геометричної форми і горстантиформного морфологічного типу, розташований в крайній південній частині Бузько-Росинського мегаблока. Варто зазначити, що раніше в літературі він фігурував як Гайворонський блок. Проте ця його назва $€$ невдалою, оскільки відповідний населений пункт (с.м.т. Гайворон) розташований за межами цієї структури.

3 південного заходу блок обмежений Подільською, а з північного сходу - Ободівською і Гайворонівською зонами розломів. Загалом, на рівні ерозійного зрізу він характеризується складною геологічною будовою, що знаходить відображення відповідно і в складній структурі геофізичних полів. Від 
сусідніх блоків відрізняється високим рівнем напруженості гравітаційного і магнітного полів та контрастно вираженою мозаїчністю магнітного поля - через наявність великої кількості максимумів $\Delta \mathrm{Ta}$ ізометричної й еліпсоподібної форм, які спричинені виходами на сучасний ерозійний зріз порід метабазитового складу.

Геологічну основу блока складають граніти палеопротерозойського побузького комплексу, серед яких у вигляді ерозійних вікон поширені ендербіти гайворонського комплексу. Серед тих та інших часто трапляються скіаліти метаморфічних порід палеоархейської дністровсько-бузької серії.

Загалом, слід відмітити неоднорідну будову Кодимсько-Тилігульського блока по латералі. У східній його частині виокремлюється Завалівсько-Ананьївський блок III порядку (структурно-формаційна підзона), східна частина якого відома ще як Синицівська зона, або "протока" [22], Саврансько-Синицівська підзона [6] і Тилігульський блок [8]. В ЗавалівськоАнаньївському блоці поєднуються породи, властиві для трьох геоструктур: Побузького і Росинсько-Тікицького блоків та Голованівської шовної зони. Так, поряд з метаморфічними породами дністровсько-бузької серії й ендербітами гайворонського комплексу тут розвинені метаморфічні утворення бузької і росинсько-тікицької серій, а також ультраметаморфічні гранітоїди тетіївського та двопольовошпатові граніти уманського комплексів.

Завалівсько-Ананьївський блок характеризується і своєрідними геофізичними полями. В його межах знаходяться найбільш інтенсивні для Кодимсько-Тилігульського блока гравітаційні аномалії - Бандурівський і Ананьївський гравітаційні максимуми.

Для Завалівсько-Ананьївського блока характерне поширення ізометричної, еліпсоподібної і лінійної форм складчастості. Лінійні синформи субмеридіонального простягання складені гнейсами, кристалічними сланцями і амфіболітами мизинівської і лисянської товщ росинськотікицької серії та породами карбонатнозалізисто-кременистого складу володарсько-білоцерківської товщі.

Контрастно виражена в геофізичних полях ізометрична Бандурівська синформа, розміром 18х20 км, має зонально-концентричну будову і відповідає однойменному, унікальному для західної частини Ущ гравітаційному максимуму. Ядерна частина (4х6 км), якій відповідає інтенсивна від'ємна аномалія магнітного і максимум гравітаційного полів, представлена утвореннями бузької серії і немагнітними метагаброїдами капітансько-деренюхінського комплексу. Зовнішній пояс складений ендербітами гайворонського та гранітоїдами побузького комплексів, серед яких поширені пачки метаморфітів бузької і дністровсько-бузької серій. Бандурівська синформа розглядається як глибокоеродована палеовулканічна структура, з якою пов'язуються перспективи алмазоносності [10].

Подібна за речовинним складом, але менша за розміром (2×4 км) і ще слабко вивчена Кідрасівська структура розташована на захід від Бандурівської.

Ананьївська синформа еліпсоїдальної форми, розміром 10х20 км, витягнута в субмеридіональному напрямку, 3 невеликим відхиленням по простяганню на північний захід. Виділяється на фоні складного мозаїчного поля інтенсивними позитивними аномаліями магнітного і гравітаційного полів. Складена різною мірою амфіболізованими двопіроксеновими сланцями, які перешаровуються 3 пластами магнетитових кварцитів і кальцифірів бузької серії.

Досить поширеними в південно-східній частині Завалівсько-Ананьївського блока $€$ купольна і лінійно витягнута складчастість. Лінійні складки складені метаморфічними утвореннями лисянської і мизинівської товщ росинсько-тікицької серії, тоді як купольні структури - гранітоїдами тетіївського комплексу.

За результатами вивчення гранітоїдних порід південно-східної частини РосинськоТікицького і Тилігульського блоків та Синицівсько-Савранської підзони [5] встановлено, що однотипові породні групи гранодіорити і плагіограніти неоархейського тетіївського і двопольовошпатові граніти уманського комплексів - у всіх цих трьох районах за петрогеохімічними особливостями майже однакові. Деякі відмінності пов'язані з їх різним рівнем ерозійного зрізу.

Подібні до Завалівсько-Ананьївської накладені неоархейські структури, в яких 
поширені утворення амфіболіт-гранулітової й амфіболітової фацій метаморфізму, також виділяються і в західній частині КодимськоТилігульського блока - це Вапнярський блок III порядку (або структурно-формаційна підзона) і власне південна частина самої Немирівської тектонічної зони. Деякими авторами ці структури виокремлюються як накладені пояси регресивного метаморфізму [15, 19, 21, 22].

Вапнярська підзона розвитку куполоподібних структур, основними з яких $€$ Ігнатківський, Крижопільський, Требусівський, Качківський та інші менші купола овальної й округлої форм, розміром від 5 до 2030 км у поперечнику, розташована в приграничній смузі з Немирівським розломом [17]. Купола в ній витягнутою віссю орієнтовані в північно-східному напрямку і складені лейкократовими гранітоїдами бердичівського комплексу, серед яких спостерігаються останці ендербітів гайворонського комплексу. У складі структур облямування куполів, поряд 3 метаморфітами дністровсько-бузької, розвинені породи бузької серії, які представлені нерозчленованою товщею амфібол-піроксенових гнейсів і кристалічних сланців та вище залягаючою хащувато-завалівською світою, що складена пачкою перешарування гнейсів і кристалічних сланців 3 метабазитами, кальцифірами і піроксен-магнетитовими кварцитами залізорудної формації [17]. Породи обрамлення, як правило, мають круте (під кутом 75-90 ) падіння. Куполоподібна форма цих структур досить добре проявляється в магнітному полі, оскільки самі по собі купола характеризуються спокійним зниженим магнітним полем. Для обрамлення ж характерне підвищене складно диференційоване поле з різким горизонтальним градієнтом [17, 19].

У межах південної частини Немирівської тектонічної зони розвинені біотитвміщуючі гнейси і кристалічні сланці та метасоматично змінені кальцифіри бузької серії, а також сублужні граніти з магнетитовою і рідкіснометалевою мінералізацією, формування яких, очевидно, пов'язане з тектоно-магматичною активізацією зони [17]. Це дає підстави вважати, що Немирівська зона розломів $€$ конседиментаційною структурою щодо бузької серії. При цьому необхідно звернути увагу на те, що територія на захід від Немирівської тектонічної зони характеризується іншим стилем складчастості. ї̈̈ структурний план обумовлений лінійними структурами північного і північно-східного простягання та великими структурами куполоподібної форми.

В межах Вапнярського блока виокремлюється субмеридіональна Воронково-Косницька синформна зона (за даними молдавських геологів, ранньопротерозойська Немирів-Воронково-Страшівська рифтогенна зона /трогова депресія), протяжністю близько 40 км, яка складена метаефузивами основного складу, магнезіальними кальцифірами і залізисто-кременистими породами, а також асоціюючими 3 ними інтрузивними утвореннями - метаультрабазитами і метагабро-піроксенітами [17, 18 та ін.]. Така породна асоціація, як вважають ці дослідники, характерна для бузької серії району Середнього Побужжя, а саме для Саврансько-Синицівської підзони.

Крім того, слід також відмітити, що на значному віддаленні від вище описаних палеотрогових зон (ближче до центральної частини Кодимсько-Тилігульської горст-антиформної структури) встановлена ще одна окремо розташована Білокам'янська синформа ізометричної форми з крутопадаючими обмеженнями, яка також, очевидно, є палеовулканічною структурою. Складена вона типовими для бузької серії метабазитами, карбонатними і залізисто-кременистими породами.

На думку П. С. Верем'єва [4], складчастість Кодимсько-Тилігульського блока, загалом, має не глибинну (тобто діапірову), а "брилову" природу. Ці брили, що складені палеоархейськими породами, зцементовані неоархейськими утвореннями. Їх сучасна морфологія зумовлена тим, що давні брили блокованого палеоархейського фундаменту в пізніші етапи тектогенезу зазнали горизонтальних і вертикальних рухів, через що вони набули внаслідок деструкції крайових зон овальної й округлої форм. У вузьких синкліналях по периферії цих куполів відкладався теригенний матеріал, а по ослаблених зонах вздовж розломів відбулось вкорінення магматичних розплавів основного складу, за рахунок яких пізніше сформувались амфіболіти й амфіболові кристалічні сланці. Загалом, 
для цих міжблокових зон характерна лінійна ізоклінальна складчастість, що простягається вздовж їх контурів. Як вважає П. С. Верем'єв, структурні особливості зон обрамлення куполів сформувались внаслідок горизонтальних переміщень жорстких брил давніх блоків, а неоархейські утворення за умовами формування належать "епікратонним утворенням, що сформувались на зануреній древній основі" [4, с. 73].

Таким чином, зони розвитку порід бузької і росинсько-тікицької серій в межах Кодимсько-Тилігульського блока, як і в сусідній Голованівській шовній зоні [23], в генетичному відношенні являють собою сильно еродовані депресійні палеотрогові зони, що сформувалися в геодинамічних умовах проторифтогенезу, і є накладеними структурами на кратонізований палеоархейський субстрат. В їх межах відмічаються фрагменти окремих вулканічних, вулкано-плутонічних і вулкано-тектонічних (кальдерні западини) структур, які чергуються з виступами нижньоархейської грануліт-ендербітової основи.

Гайсинський блок II порядку, близької до прямокутної форми, обмежений Ободівською і Дашівською (на північному сході) розломними зонами. Від КодимськоТилігульського блока відрізняється відносно дещо зниженими гравітаційним і магнітним полями, однак в ньому, загалом, ще зберігається мозаїчний характер структури магнітного поля. Причому зниження напруженості полів відбувається у північному напрямку. Такий характер поля зумовлений близьким заляганням палеоархейської кристалічної основи до рівня сучасної земної поверхні.

В межах Гайсинського блока чітко виокремлюються два блоки III порядку - Теплицький і Тульчинський. Південний Тульчинський блок клиноподібної форми обмежений Ободівською і Хмільницькою тектонічними зонами. Для нього характерний широкий розвиток утворень палеоархейського грануліт-ендербітового структурно-формаційного комплексу, який переважно поширений в східній частині блока серед пізніше розвинутих по ньому гранітоїдів побузького комплексу. В західній його частині здебільшого поширені гранітоїди тетіївського і граніти уманського комплексів з останцями палеоархейських грануліт-ендербітових утворень.

Геологічну основу північного Теплицького блока III порядку утворюють граніти уманського комплексу, яким властиве від'ємне магнітне поле. На фоні останнього виокремлюються лінійні позитивні аномалії субширотного до північно-східного простягання в східній частині і до північно-західного - в західній, що зумовлені ультраметаморфічними гранітоїдами гайсинського і тетіївського комплексів з частими скіалітами амфіболітів росинсько-тікицької серії.

У східній частині Теплицького блока також виокремлюються ланцюжки кулісно розташованих позитивних аномалій, спричинених пачками діафторованих метаморфітів дністровсько-бузької серії, які згруповані в зони субширотного простягання. Чітко виокремлюються три такі зони поширення скіалітів цих порід шириною 2-5 км і протяжністю до 20 км. Вони являють собою релікти антиформних складок північно-східної орієнтації. Між цими позитивними структурами розташовані брахісинформні споруди, складені гранітами тетіївського комплексу з частими скіалітами росинсько-тікицької серії.

Уманський блок II порядку, що в плані наближується до ромбоподібної форми, характеризується зниженим рівнем напруженості гравітаційного і магнітного полів і значно простішою ї внутрішньою структурою. На фоні відносно спокійного магнітного поля виокремлюються численні максимуми ізометричної і лінійно витягнутої форми, переважно меридіонального і північнозахідного простягання.

Більша південна частина Уманського блока складена гранітами однойменного масиву, серед яких у вигляді ерозійних виходів спостерігаються плагіогранітоїди тетіївського комплексу та метаморфіти росинсько-тікицької серії. Для центральної частини блока характерне приблизно рівне співвідношення ультраметаморфічних утворень тетіївського й уманського комплексів. У північній частині зазначеного блока відмічається часте чергування ділянок, представлених гранітами уманського і плагіогранітами тетіївського комплексів, при переважанні складових першого комплексу. 
Зазначені гранітоїди досить чітко вирізняються в магнітному полі. Так, для двопольовошпатових гранітів уманського комплексу характерне спокійне поле. Діоритам і кварцовим діоритам тетіївського комплексу відповідає диференційоване магнітне поле з численними низькоградієнтними аномаліями різної форми й орієнтування [7].

Внаслідок широко проявленої в межах блока гранітизації порід суперкрустальні утворення збереглися у вигляді невеликих останців різних розмірів і форм серед гранітоїдів. Вони виділяються як лінзоподібні синформи - фрагменти глибокоеродованих структур, які збереглися від гранітизації. Простежуються по простяганню на відстань 7-8, іноді до 10-15 км, при ширині 4-6 км. Такі структури в магнітному полі виокремлюються високоградієнтними аномаліями. За результатами геологічного довивчення [7] виділені Іванківська, Лосятинська, Березнянська, Озернянська та інші невеликі синформи, які в ядерних частинах складені гнейсами лисянської товщі, а на крилах - амфіболітами та кристалічними сланцями мизинівської товщі. Витягнутою віссю вони орієнтовані переважно на північний захід, а поблизу Тальнівського розлому ці структури мають субмеридіональне простягання. За ланцюжковим розташуванням таких скіалітів можна виокремити осі окремих більших синформ.

У межах аркуша "Біла Церква" виокремлені Терезинська, Насташківська, Улашівська, Кирданівська і Житньогірська синформи, до ядерної частини яких приурочені карбонатно-залізисто-кременисті утворення володарсько-білоцерківської товщі [7], що фіксуються високоінтенсивними локальними максимумами магнітного поля.

Білоцерківський блок II порядку складної форми займає північну частину Бузько-Росинського мегаблока. Від Уманського блока виокремлюється Центральною тектонічною зоною і за геофізичними даними відрізняється більш сильно диференційованими полями. В його межах розміщений Фастівський гравітаційний максимум і Бориспільський магнітний мінімум. За їх територіальним поширенням у межах зазначеного блока можна виокремити відповідно два блоки III порядку, що розмежовуються по меридіональному Дарницькому розлому.
Східний Бориспільський блок в основному характеризується слабо диференційованими і слабо градієнтними магнітним і гравітаційним полями. У геологічній будові цього блока провідна роль належить гранітам уманського комплексу.

В межах західного Фастівського блока гравітаційне і магнітне поля сильно диференційовані, знакоперемінні і складаються з чергування максимумів і мінімумів різної форми й орієнтації. В його будові беруть участь переважно гранітоїди тетіївського комплексу, які насичені останцями і реліктами гнейсів росинсько-тікицької серії та габроїдів юрівського комплексу.

На закінчення слід сказати, що, незважаючи на інтенсивне перетворення метаморфічних порід гранітизаційними процесами і неможливість виокремлення в межах Бузько-Росинського мегаблока великих плікативних структурних елементів, проте (враховуючи відносно детальну закартованість території) на геологічних картах все ж таки чітко виокремлюється східна частина, в якій поширені останці гнейсів лисянської товщі, і західна, де розвинені амфіболіти і біотит-амфіболові кристалічні сланці мизинівської товщі росинсько-тікицької серії. Зазначена закономірність також чітко проявляється і в фізичних полях: у східній частині спостерігаються спокійні гравітаційне і магнітне поля, тоді як у західній вони диференційовані ділянками мозаїчної структури. Ці закономірності дозволяють реконструювати дві складчасті зони догранітизаційного етапу тектогенезу - східну синформної і західну антиформної будови. Остання ускладнена меншою синформною складчастістю.

\section{Висновки та пропозиції}

Бузько-Росинський мегаблок $є$ самостійним геоструктурним елементом УЩ, який сформувався протягом двох великих етапів тектонічної еволюції раннього докембрію, внаслідок чого він нині має двоярусну будову. Нижній ярус представлений палеоархейським грануліт-ендербітовим структурно-формаційним комплексом, а верхній складений неоархейськими метаморфічними утвореннями бузької і росинсько-тікицької серій. Вирізнені в межах мегаблока менші 
блоки (Росинсько-Тікицький і Середньобузький I порядку та Кодимсько-Тилігульський, Гайсинський, Уманський і Білоцерківський II порядку) характеризуються різним рівнем ерозійного зрізу і відрізняються між собою за особливостями геофізичних полів, речовинним складом стратифікованих і нестратифікованих утворень і відповідно різним ступенем метаморфізму та гранітизації.

Розташований в південній частині мегаблока гетерогенний за складом і неоднорідний за будовою Кодимсько-Тилігульський блок II порядку, де переважно поширені палеоархейські утворення нижнього ярусу, являє собою горст-антиформне підняття, що розділяє його північну частину і південне занурення щита (південний фланг Білоцерківсько-Одеської структурно-формаційної зони - Молдавську плиту), які в основному складені однотиповими стратигенними утвореннями росинсько-тікицької серії. Виокремлені в межах цього блока структурно-формаційні підзони (блоки більш високого рангу) - ЗавалівськоАнаньївська, Вапнярська і Південно-Немирівська з розвиненими в них утвореннями двох зазначених неоархейських серій, $€$ зв'язуючою ланкою між північною частиною Бузько-Росинського мегаблока і Кишинівським блоком Молдавської плити.

У генетичному аспекті зони розвитку порід бузької і росинсько-тікицької серій в межах Кодимсько-Тилігульського блока являють собою сильно еродовані депресійні палеотрогові зони, які були сформовані в геодинамічних умовах проторифтогенезу і накладені на кратонізований палеоархейський субстрат. В їx межах відмічаються фрагменти окремих вулканічних, вулкано-плутонічних і вулкано-тектонічних (кальдерні западини) структур, які чергуються 3 виступами нижньоархейської грануліт-ендербітової основи.

На підставі викладеного в схему структурно-тектонічного районування УЩ, що раніше була прийнята як основа для Кореляційної хроностратиграфічної схеми... [16], пропонується внести уточнення щодо виокремлення в західній частині УЩ таких мегаблоків: Волинського, Подільського і БузькоРосинського.

1. Безвинний В. П. Особливості геологічної будови та складу супракрустальних і ультраме- таморфічних утворень Росинсько-Тікицького блока Українського щита: Автореф. дис. ... канд. геол. наук. - К., 2008. - 16 с.

2. Безвинний В. П., Орса В. І. Суперкрустальні утворення Росинсько-Тікицького мегаблоку Українського щита // Мінерал. журн. - 2006. № 3. - С. 106-111.

3. Бєлєвцев Я. М., Прус А. К. Основні етапи геологічного развитку Українского щита // Геол. журн. - 1962. - Т. 22, вип. 5. - С. 3-27.

4. Веремьев П. С. Основные черты тектоники докембрия Подольского Приднестровья // Там же. - 1974. - Т. 34, вып. 1. - С. 62-74.

5. Войновський А. С., Шварц Г. А., Безвинний В. П. та ін. Речовинний склад гранітоїдів докембрію Синицівсько-Савранської підзони (Середнє Побужжя) // Мінер. ресурси України. - 2009. - № 1. - С. 24-29.

6. Державна геологічна карта України. - М-б 1:200 000. Центральноукраїнська серія. Аркуш М-36-XXXI (Первомайськ) / Клочков В. М., Білинська Я. П., Веклич Ю. М. та ін. К.: Держ. ком. природ. ресурсів України, УкрДГРІ, 2004. - 175 с.

7. Державна геологічна карта України. - М-б 1:200 000. Центральноукраїнська серія. Аркуші М-36-XIX (Біла Церква), М-36-XXV (Умань) / Безвинний В. П., Циба М. М., Донець Г. А. та ін. - К.: Держгеолслужба, пДРГП "Північгеологія", 2006. - 165 с.

8. Державна геологічна карта України. - М-б 1:200 000. Центральноукраїнська серія. Аркуш L-I (Любашівка) / Шварц Г. А., Філатова Л. С., Іванов А. І. та ін. - К.: Мін. охорони навкол. природ. середовища України, Держгеолслужба, Причор. держ. регіон. геол. підприємство, 2007. - 144 с.

9. Доброхотов М. Н. О геологии Белоцерковско-Одесской структурной зоны Украинского щита // Геол. журн. - 1974. - Т. 34, вып. 6. C. 84-95.

10. Довгань Р. Н., Ентин В. А., Павлюк В. Н. Бандуровская палеовулканическая структура и связанные с ней перспективы алмазоносности // Мінер. ресурси України. — 2006. - № 4. C. 22-28.

11. Дранник А. С., Костенко М.М., Єсипчук К. Ю. та ін. Геолого-структурне районування Українського щита для уточнення стратиграфічної кореляції докембрійських утворень // Там же. - 2003. - № 1. - С. 26-29.

12. Єнтін В. А., Шимків Л. М. Щодо геофізичної обґрунтованості мегаблокового принципу 
районування для стратиграфічної кореляції докембрійських утворень Українського щита // Там же. - 2004. - № 1. - С. 12-13.

13. Каляев Г. И. Тектоника докембрия Украинской железорудной провинции. - Киев: Наук. думка, 1965. - 190 с.

14. Каляев Г. И., Глевасский Е. Б., Димитров Г. Х. Палеотектоника и строение земной коры докембрийской железорудной провинции Украины. - Киев: Наук. думка, 1984. - 240 с.

15. Кирилюк В. П., Смоголюк А. Г. Об основных элементах этажно-блоковой структуры Украинского щита // Геол. журн. - 1993. - № 3. С. 54-69.

16. Кореляційна хроностратиграфічна схема раннього докембрію Українського щита. Пояснювальна записка. - К.: УкрДГРІ, НСК України, 2004. - 30 с.

17. Крутиховская 3. А., Чебан И. Т., Мельничук Э. В., Слоницкая С. Г. О строении Немировской зоны разломов в южной части Украинского щита и направлении поисков полезных ископаемых // Геол. журн. - 1985. - Т. 45, № 1. C. $47-57$.

18. Нечаев С. В. Основные черты геологического строения и особенности рудной минерализации Подольско-Приднестровского выступа Украинского щита (прогнозно-поисковый аспект) // Зб. наук. пр. УкрДГРІ. — 2008. - № 3. C.33-44.
19. Рябенко В. А. Основные черты тектонического строения Украинского щита. - Киев: Наук. думка, 1970. - 128 с.

20. Соллогуб В. Б., Чекунов А. В., Трипольский А. А. Тектоническое районирование Украинского щита в свете данных глубинных геофизических исследований // Геол. журн. - 1972. Т. 32, вып.4. - С. 47-57.

21. Усенко И. С., Щербаков И. Б., Сироштан Р. И. и др. Метаморфизм Украинского щита. - Киев: Наук. думка, 1982. - 308 с.

22. Щербаков И. Б. Петрология Украинского щита. - Львов: ЗУКЦ, 2005. - 366 с.

23. Ярощук М. А. Гнейсо-гранулитовые комплексы Голованевской шовной зоны Украинского щита // Геологія і магматизм докембрію Українського щита. - К., 2000. - С. 118-119.

24. Ярощук М. А. Железорудные формации Белоцерковско-Одесской металлогенической зоны. - Киев: Наук. думка, 1983. - 223 с.

25. Ярощук М. А., Вайло А. В., Савченко Л. Т. Генетические особенности пород железистокремнистой формации Фрунзовской зоны Украинского щита // Геол. журн. - 1989. № 3. - C. 105-112.

Голов. від-ня УкрДГРІ,

Стаття надійшла

Київ

29.06.10 